\title{
Determinants of Employee Performance: Study of Workability, Organizational Commitment and Professionalism in the Land Offices
}

\author{
Bayu Chrisdianto $^{1} \quad$ Harianto Respati ${ }^{2}$ \\ 1.Student of Postgraduate Magister Management, University Merdeka of Malang, Indonesia \\ 2.Economics and Business Faculty, University Merdeka of Malang, Indonesia
}

\begin{abstract}
The purpose of this study is to examine the impact of workability, organizational commitment, and professionalism on employees performance. In addition, this research finds symptoms that have a high impact on employee performance for future work target decisions. This research was conducted at the service office for land ownership in Indonesia. Questionnaires are used to collect data.The number of office employees was 68 people and the data collection technique is a census. The design of this study was quantitative with three proposed hypotheses. The results of the study have proven that workability, organizational commitment, and professionalism have a positive significant effect on employee performance.The workability of employees turned out to provide the highest influence on employee performance.Creativity, innovation, and responsiveness are part of the workability of employees that are very necessary for government organizations that have high levels of performance and work targets, such as in the Land Offices in Indonesia.
\end{abstract}

Keywords: workability, organizational commitment, professionalism, employee performance, land offices DOI: $10.7176 / \mathrm{EJBM} / 11-23-09$

Publication date: August $31^{\text {st }} 2019$

\section{Introduction}

It has been stated in Presidential Regulation No. 17 of 2015 that the Ministry of Agrarian and Spatial Planning / National Land Agency (ATR / BPN) obtains a mandate from the President to carry out the task of carrying out the formulation and implementation of policies in the field of survey, measurement, and mapping in accordance with the provisions of the applicable legislation. There are three strategic targets of the Ministry of Agrarian and Spatial Planning / National Land Agency (ATR / BPN), namely: 1. Community welfare through agrarian, 2. Materializing a safe, comfortable, productive space. 3. Disputes / conflicts / agrarian cases are reduced.To implement this, reliable human resources are needed to realize overall performance achievements.

The role of the organization, Sutrisno (2012) has explained that an organization needs the role of reliable human resources in decision making. The main element in the organization is the role of Human Resource. Organizational activity is very dependent on the ability, commitment and professionalism of employees to achieve organizational goals, even by Sedarmayanti (2014) specifically explained that good/reliable human resources become a guarantee for organizational goals.

The Republic of Indonesia is a country with the fourth-largest population in the world with 258,704,900 in 2017 with a land area of 1,922,570 km2 (BPS, 2017). This abundant wealth must be managed well for the prosperity of the people by prioritizing the legal certainty in the agrarian sector so that the people have a guarantee of security and comfort in order to be productive.

The President of the Republic of Indonesia mandated the Ministry of Agrarian Affairs and Spatial Planning / National Land Agency (ATR / BPN) to immediately implement a systematic Land Registry to accelerate land titling throughout Indonesia until 2025.Efforts to accelerate the Ministry of Agrarian Affairs and Spatial Planning / National Land Agency are carried out by targeting land tenure with a roadmap for 2017 of 5 million fields, 2018 as many as 7 million fields, 2019 as many as 9 million fields and 2020 as many as 20 million fields, until 2025 It is expected that all land parcels in Indonesia will be completed.

The Ministry of Agrarian and Spatial Planning / National Land Agency (ATR / BPN) has a strategic role to support the achievement of the National Development, namely improving the quality of Indonesian human life through improving the quality of education and training with the "Smart Indonesia" program and improving the welfare of the community with the"Indonesia Employment, Prosperous Indonesia "program by encouraging a 9 million hectare land ownership program in Indonesia in 2019.

Until now, survey, measurement, and mapping of land parcels have been carried out by the Provincial Land Office and the Regency / City Land Office.For the city of Malang, with a number of land parcels of approximately 290,000 fields, up to October 2018, there have been registered 232,681 (approximately 80\%) of land parcels that already have certificates of land rights.

Mahsun (2006) has explained that organizational performance is determined by individual/employee performance.He also explained that performance is a description of the level of achievement of an organization's 
goals or objectives both in quality and quantity.In terms of quantity, the Malang City Land Office has achieved work targets in accordance with the plan to support 9 million hectares of land ownership for 2019.To carry out the role, function for the achievement of work targets, the Land Offices in Malang City is supported by human resources from various disciplines and educational strata. This diversity has become the strength of the organization to achieve work goals. Robbins (2013) has explained performance, that is a result achieved by employees according to certain criteria for a job. Robbins (2013) also mentioned that individual performance can be measured by several measures such as the quality of work, the quantity of work and the timeliness of employee work.

The ability of employees to be the main capital to achieve organizational goals. To improve performance optimally, it takes the abilities and skills of employees in accordance with their expertise.Efforts to improve employee capacity have become a major concern of every element of leadership in order to achieve organizational success. Increasing the ability of each employee is expected to lead to the potential of the organization in achieving the goals that have been set.

Ability is the maturity of a person related to the skills or knowledge that has been obtained from the process of education/training and experience.

The results of observations of the researchers can be explained that the performance of employees at the Land Officesin Malang City is caused by the ability of employees to perform technical matters, employees are able to do it quickly especially in terms of data collection and measurement of land in urban and rural areas; communication skills and relationships with fellow colleagues are good.In addition, the concept of employee ability is classified as good, this is due to educational and training backgrounds to support government programs.

Mangkunegara (2014) has explained that one of the causes of individual performance is influenced by ability.Robin and Judge (2013) interpret employee workability as a capacity possessed by employees in carrying out their duties or jobs relevant to the level of training, education, and experience.Observations in the field show that training is a top priority for organizational goals. The results of Syardiano's research (2014) which examined the workability and performance of the Department of Transportation, Communication and Information of East Kutai Regency explained that the workability of employees had an effect on performance.

As explained by Mangkunegara (2014) and Syardianto's research (2014), it is necessary to do a test to reinforce the relationship between workability and performance of government employees in the Land Offices.

The clarity between workability and employee performance at the land office needs to be tested, so that:

H1: Workability has a significant effect on employee performance

In addition to discussing the workability of employees, based on observations of researchers there are other factors that can affect employee performance, namely organizational commitment.

It has been explained according to Jewell and Siegall (2010) that organizational commitment is a condition that employees are still in favor of the organization in order to achieve organizational goals.

Sopiah (2010) has explained that organizational commitment is part of an individual's behavior to survive as an organizational membership and mobilize all the capabilities they have for organizational purposes. The observations explain that employees in the Land offices have the good organizational commitment, this shows that the behavior of employees still adheres to the rules that apply to daily tasks related to community service, has the willingness to complete work, is loyal to the organization and proud as a public servant.Kusnendi (2011) has tried to link between organizational commitment and individual performance.

Kusnendi (2011) has concluded that organizational commitment is still important to create conducive working conditions so that employees can work effectively and efficiently to achieve goals. Salma (2016) has examined the effect of organizational commitment on employee performance in the Morowali Sulawesi District Health Center, which has shown that there were significant influences.

Regarding the results of research conducted by Salma (2016) and Kusnendi's (2011) statement, it is necessary to conduct an examination between organizational commitment and individual performance at the Malang City Land Office to be explained in more depth.

An organization must have employees who are professional in carrying out daily tasks to achieve organizational goals (Siagian, 2000).

Siagian (2000) also explained that professionalism as a form of the sincerity of employees to work in quality is able to use time well.Employee professionalism appears in the ability to utilize activities to look for opportunities and chance that exist for specific individual performance goals and organizational performance in general.Professional employees have the ability and skills through education, training, and experience. The clarity between organizational commitment and the performance of employees in the land office is important to do testing, so that:

H2: Organizational commitment has a significant effect on employee performance

The professionalism of employees in the government bureaucracy, such as in the Land Offices in Malang City, is a necessity to achieve better work results.On the other hand, the standard of professionalism in the bureaucratic environment still has no definite standard.Employees' intellectuality is a determining factor in 
behaving professionally within the government bureaucracy.Observations have shown that creativity, innovation, and responsiveness of Land Offices in Malang City to complete work according to the target can be categorized as good.Every month the leader explains the work plan that must be completed.According to the results of previous observations that the Land offices employee in Malang City was able to complete the work target in accordance with the provisions, although there were still some obstacles.

The results of Windura et al (2017) study have examined the influence of employee professionalism on the performance of government employees in Dumai City found that there were significant influences.Based on Windura et al (2017) findings, it is necessary to examine the professionalism of government employees in the Land Offices in Malang City, including creativity, innovation, and responsiveness toward employee performance consisting of quality, quantity, and timeliness of employee work.

Clarity between the professionalism and performance of employees at the land office needs to be tested, so that:

H3: Professionalism has a significant effect on employee performance

At present, human resource governance in the Land offices has difficulty finding the right way to optimize employee performance.Meanwhile, the work target of the Ministry of Agrarian and Spatial Planning / National Land Agency for the 9 million hectare land ownership program in Indonesia must be completed by 2019.Based on this reason, the results of testing in this study can help explain the determinants of employee performance,so that office leaders are easy to plan in increasing employee potential.

\section{Theoretical Study}

This study examines the impact of variable workability, organizational commitment, and professionalism on employee performance.Performance according to Robbins (2013: 264) has defined that performance is a result that is captured by employees in their work according to certain criteria for a job.Performance explains the target of the work of government employees. The performance of government employees can be measured by the quality, quantity of work produced and the timeliness of work. The quantity of work is characterized by the ability of employees to complete many jobs, employees can complete work on time and leaders believe in the ability of employees. The quality of work is characterized by characteristics such as being able to complete work in accordance with the standard provisions, the work of employees is completed well and no complaints occur.Government employees who work in a timely manner are characterized by the ability to complete work in accordance with the specified time, quickly complete the work and quickly report.

Robbins and Judge (2013: 52) have explained that workability is the capacity of individuals to carry out various tasks. The ability of government employees can be explained by knowledge and skills in carrying out work. The workability of government employees is measured by technical capabilities, human abilities, and conceptual abilities.Employees' technical capabilities can be seen from the ability of employees to understand work procedures, use equipment, work experience, be able to follow work procedures and be able to work more efficiently.Human ability can be known from the ability of employees to communicate, relationships between employees, able to resolve conflicts with colleagues.Conceptual capabilities of government employees can be seen from the ability to analyze information, design concepts and anticipate changes.

Sopiah (2010) has explained organizational commitment is an important behavioral dimension that can be used to assess the tendency of employees to survive as members of the organization.Organizational commitment for government employees is a sense of trust in organizational values, willingness to try as best as possible in the interests of the organization and the desire to remain a member of the organization.Organizational commitment for government employees is measured by the willingness of employees, loyalty, and pride of employees. The willingness of employees is measured by compliance with regulations, willingness to be monitored, and being able to succeed in office work programs.

Professionalism according to Siagian (2000) was a form of seriousness in carrying out tasks in order to produce good quality work, use of the right time and be able to work according to the right procedures. The professionalism of government employees is characterized by expertise in carrying out work according to the professional field.Employee professionalism is measured by creativity, innovation, and responsiveness. The creativity of government employees explains the ability to plan work, make feedback and create work.Innovation can be measured by the ability of employees to complete complex work. Employee responsiveness can be seen in communication skills.

\section{Research methods}

This study examined four variables, namely workability, organizational commitment, professionalism as independent variables and employee performance as dependent variables.

of land affairs in Malang city as the location of the research location with 63 offices employees. This number is in accordance with the number of research samples so that the technique of data collection is the census method.Data collection using a Likert scale questionnaire with choice 5 very agrees until choice 1 is strongly 
disagree, choice 3 is neutral.The research period is conducted in August 2018.Multiple linear regression techniques as a research analysis tool are used to prove the hypothesis and answer the problem of this research.

\section{Research result}

\section{Characteristics of respondents}

The questionnaire was circulated to 68 employees. The collected data has been tabulated. Profile of respondents showed male gender as much as $41 \%$ and $22 \%$ were women.Most respondents aged more than 50 years were $43 \%$, less than 30 years were $6 \%$, ages 31 to 40 were $17 \%$, and age $41-50$ was $33 \%$. The education level of most respondents is a bachelor of $38 \%$, graduating high school $33 \%$, diploma level $24 \%$ and postgraduate $5 \%$. The conclusion of the respondent's profile is that they have better knowledge and work experience.

\section{Test Results and statistical descriptions}

Researchers have tested the validity and reliability of research instruments. The number of questionnaires dependent variable employee performance was 6.The independent variable of workability was 11 pieces.Free commitment variable as many as 8 pieces.Professionalism variables were 8 pieces. The results of testing the validity for 25 questionnaires proved to produce moment product correlation numbers exceeding 0.7 with a probability level of less than 0.05.This is consistent with the statement Nunnally and Bernstein (1994) that if the results of the correlation value exceed 0.7 , the item questionnaire is declared valid.

Table 1. Questionnaire reliability test results

\begin{tabular}{|l|c|c|}
\hline \multicolumn{1}{|c|}{ Variables } & Cronbach's $\alpha$ & Cut - off \\
\hline KP Employee performance & 0,870 & 0,700 \\
\hline KK Workability & 0,765 & 0,700 \\
\hline KO Organizational Commitment & 0,811 & 0,700 \\
\hline P Professionalism & 0,799 & 0,700 \\
\hline
\end{tabular}

Table 2 shows that the reliability level exceeds the recommended number of 0.7 . In accordance with Nunnally and Bernstein's statement (1994) which explains the value of Cronbach's $\alpha$ exceeds the value of 07, the analyzed instrument is declared reliable. This shows that respondents understand the questionnaire that is filled and if asked again, the respondent has a high chance to answer consistently. The results of the tabulation results analysis description of the respondent's answers are measured by statistical averages. The researcher measured the perceptions of respondents using a 5-point Likert scale.

The results of the average statistical analysis are shown in the table below:

Table 2. Results of statistical description analysis

\begin{tabular}{|c|c|c|c|c|}
\hline Variables & Indicators & Mean & Item Questionnaire & Mean \\
\hline \multirow{8}{*}{$\begin{array}{l}\text { KP Employee } \\
\text { Performance }\end{array}$} & \multirow[t]{2}{*}{ KP1 Quantity } & \multirow[t]{2}{*}{3.93} & KP11 The work target is reached & 4.17 \\
\hline & & & KP12 Quickly get the job done & 3.80 \\
\hline & \multirow[t]{3}{*}{ KP2 Quality } & \multirow[t]{3}{*}{3.85} & KP21 According to work standards & 4.22 \\
\hline & & & KP22 Better than work standards & 3.87 \\
\hline & & & KP23 Low complaint & 3.47 \\
\hline & \multirow[t]{3}{*}{ KP3 On-time } & \multirow[t]{3}{*}{4.01} & KP31 Complete on time & 4.06 \\
\hline & & & KP32 Work faster & 3.96 \\
\hline & & & KP33 Quickly report work & 4.00 \\
\hline \multirow[t]{11}{*}{ KK Workability } & \multirow[t]{5}{*}{ KK1 Technical } & \multirow[t]{5}{*}{4.09} & KK11 Follow work procedures & 4.30 \\
\hline & & & KK12 Able to use work equipment & 3.93 \\
\hline & & & KK13 Work experience & 3.92 \\
\hline & & & KK14 does not violate work procedures & 4.38 \\
\hline & & & KK15 Simplify work & 3.95 \\
\hline & \multirow{3}{*}{$\begin{array}{ll}\text { KK2 } & \text { Human } \\
\text { relations } & \end{array}$} & \multirow[t]{3}{*}{3.95} & KK21 Able to communicate & 3.87 \\
\hline & & & KK22 Inter-employee harmony & 3.98 \\
\hline & & & KK23 Low conflict & 4.03 \\
\hline & \multirow[t]{3}{*}{ KK3 Conceptual } & \multirow[t]{3}{*}{4.04} & KK31 Analyze information & 4.14 \\
\hline & & & KK32 Make a working concept & 3.93 \\
\hline & & & KK33 Anticipating change & 4.06 \\
\hline \multirow{5}{*}{$\begin{array}{l}\text { KO Organizational } \\
\text { Commitment }\end{array}$} & \multirow{4}{*}{$\begin{array}{l}\text { KO1 Willingness of } \\
\text { Employees }\end{array}$} & \multirow[t]{4}{*}{4.03} & KO11 Comply with regulations & 3.93 \\
\hline & & & KO12 Willing to be watched & 3.96 \\
\hline & & & KO13 Serve & 4.34 \\
\hline & & & KO14 Successful work program & 3.87 \\
\hline & KO2 Allegiance & 3.97 & KO21 Faithful to the orders of superiors & 4.06 \\
\hline
\end{tabular}




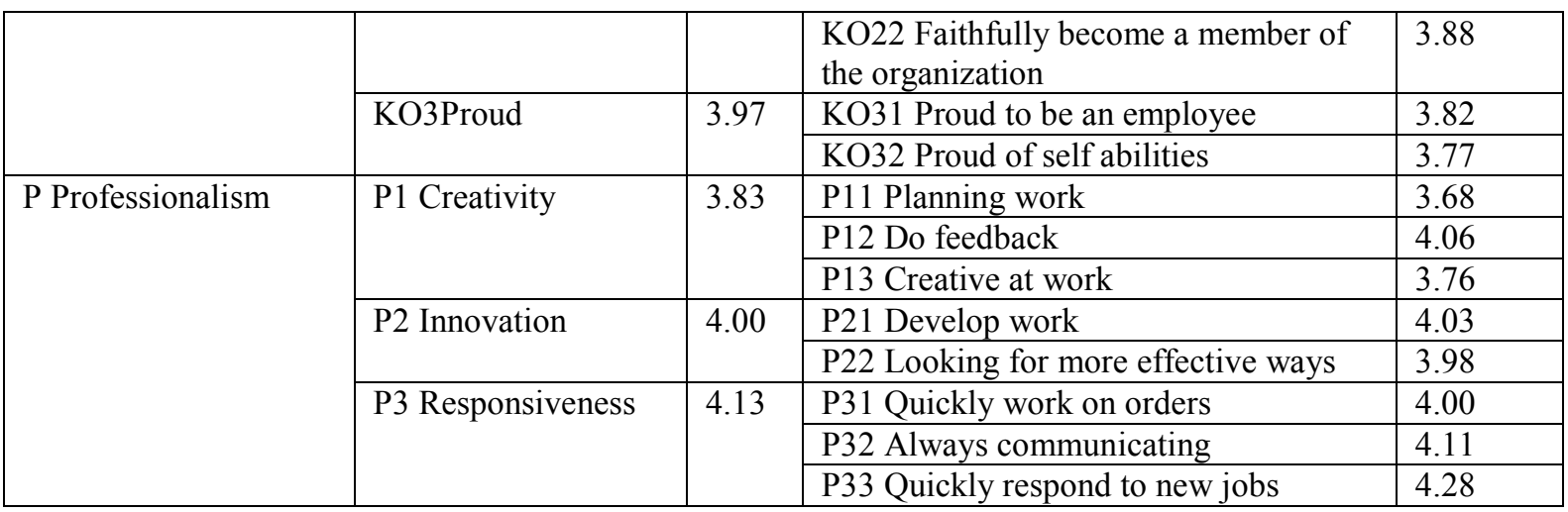

\section{Results of regression analysis}

The regression process of collected data is accessed by the SPSS statistical program (Statistical Package for Social Science).The results of the classical assumption analysis show that the data are normally distributed and free from the problem of heteroscedasticity. The results of multicollinearity analysis and autocorrelation are shown in the table below.

Table 3. Results of classical assumption analysis

\begin{tabular}{|l|l|l|l|}
\hline Variables & VIF - Variance Inflantory Factors & Cut-off & Durbin Watson \\
\hline KK-Workability & 2.89 & 10 & \multirow{2}{*}{1.325} \\
\cline { 1 - 3 } KO-Organizational commitment & 3.91 & 10 & \multirow{2}{*}{} \\
\cline { 1 - 3 } P- Professionalism & 2.26 & 10 & \\
\hline
\end{tabular}

VIF values for workability variables (2.89), organizational commitment (3.91), and professionalism (2.26) do not exceed the number 10. This comparison concluded that there were no multicollinearity problems in the variables studied, meaning that there was no strong correlation between the independent variables in the regression equation model. The value of Durbin Watson $(1,325)$ is proven between numbers -2 and 2 . This explanation shows that the data collected does not have a strong correlation between the observational data.The conclusion of the results of the classical assumption analysis is the multiple linear regression equation models fulfills the principle of the best linear unbias estimator.The results of multiple linear regression analysis for four variables consisting of one dependent variable and three independent variables are shown in the table below.

Table 4. Results of multiple linear regression analysis

\begin{tabular}{|l|l|l|l|}
\hline \multicolumn{1}{|l|}{ Variables } & Koef. standardized & $\mathrm{t}$ statistik & Remark \\
\hline WA-Workability & 0.379 & $4.427^{*}$ & H1 is accepted \\
\hline OC-Organizational Commitment & 0.321 & $3.601^{*}$ & H2 is accepted \\
\hline P- Profesionalisme & 0.251 & $3.668^{*}$ & H3 is accepted \\
\hline $\begin{array}{l}\text { EP is Employees Performance } \\
*) \text { shows a level of } \mathrm{p} \leq 0.05\end{array}$ & \\
\hline
\end{tabular}

The standardized multiple linear regression equation models obtained:

$\mathrm{EP}=0,379 \mathrm{WA}+0.321 \mathrm{OC}+0.251 \mathrm{P}+\mathrm{e}$

Workability produces a standardized coefficient of 0.379 with a level of $p(0.000) \leq 0.05$.

This comparison shows the workability has a significant effect on employee performance so that the proposed $\mathrm{H} 1$ is accepted. Organizational commitment obtained a standardized regression coefficient of 0.321 with a level of $\mathrm{p}(0.001) \leq 0.05$. This comparison shows that organizational commitment has a significant effect on employee performance so that the proposed $\mathrm{H} 2$ is accepted. Professionalism obtained a standardized regression coefficient of 0.251 with a level of $\mathrm{p}(0.001) \leq 0.05$. This comparison shows that professionalism has a significant effect on employee performance so that the proposed $\mathrm{H} 3$ is accepted.The important result of this multiple linear regression analysis is that the workability of employees has a stronger influence on employee performance than organizational commitment and professionalism.

\section{Discussion and managerial implications}

The workability of the Land Office employees measured three indicators, namely technical capabilities, human abilities and conceptual abilities of employees. The employee's perception of technical ability is that employees are able to follow work procedures effectively. This shows that in the Land Offices in Malang City has implemented strict Standard Operating Procedures for employees.Employees' perceptions of humanity that is every conflict about land issues can be resolved by employees in the right way. This shows that employees understand the type of work done so quickly and easily solve the problems that occur.

Employee perceptions of conceptual abilities such as the ability of employees to make work concepts, conduct an analysis of work and process information proved they like the ability to analyze information well.This shows 
that all workers always use information technology to convey the results of their work to their superiors and colleagues.Employees are accustomed to managing information and always updating with the information available to make the work program successful in the Land Offices. The results of the analysis of perceptions of the workability of employees in this study have been found that the workability of employees has more ability to effectively follow work procedures.

Employee perceptions of the willingness of employees were employees willing to take service activities to the community.This shows that the spirit of land employees to serve the wider community is still considered good.Employee perceptions of employee loyalty are measured by motivation for loyalty and career motivation has been proven that motivation to be loyal to organizational goals is preferred by employeesThis shows that employees have been loyal to their superiors and have the same thoughts about the organization's vision and mission. The employee's perception of employee pride is proud to be an employee in his office where he works. The results of the analysis of descriptions of organizational commitment have been found that employees have committed to spending time in community service activities.

Employee professionalism measured three indicators, namely employee creativity, innovation and responsiveness to work.Employee perceptions of creativity have been found that employees always make feedback about the results of their work. This means that they always communicate between employees about their workThis shows that the type of work in the land office with each other is interrelated so that the communication aspect is needed.Employee perceptions of employee innovation have shown that employees are able to innovate to complete work. This shows that innovation is needed to complete work on time.Many types of work must be completed immediately without violating existing procedures.

The results of the analysis of descriptions of employee professionalism have been found that employees professionally respond and carry out work quickly according to instructions from the leadership.

Employee performance is measured by three indicators, namely the results of work in quantity, quality and timeliness of work.Employee perceptions of the quantity of work of employees indicate that employees have been able to complete the number of jobs in accordance with the target organization. This shows that each employee already has a record of the number of jobs that must be completed in a certain period so that they are patterned with work that has been planned and arranged neatly.Employee perceptions of the quality of work of employees have been found that employees are able to complete work with quality that is in accordance with the provisions of the organization. The results of the description of the quality of work analysis of employees have shown that the work results of employees are in accordance with the standards. Training and work experience determine the quality of work of employees.Employees' perceptions about the timeliness of completing work are that they have been able to complete each job on time. The results of the descriptive analysis of employee performance have been found that most employees are able to complete the work on time in accordance with the targets imposed.

In 2018, for measuring and mapping land parcels carried out by the Urusa Tanah Office in Malang City there were approximately 290,000 fields and up to October 2018, there were 232,681 parcels of land that already had land rights certificates. Overall, the Ministry of Agrarian and Spatial Planning / National Land Agency has a target of 9 million hectares of land in Indonesia for 2019.To achieve this great work special expertise is needed in the Land offices in Malang City.

The performance of employees in Land Offices is measured by the number of work results of employees, the quality of work and the timeliness of completing work. The results of the descriptive analysis have shown that the timeliness of work, namely the ability of employees to complete all types of work in accordance with the time period set by the organization has the perception of the respondent with the highest ranking.

Mangkunegara (2014) has explained that one of the causes of employee performance is the workability of employees.Employees' technical abilities in following the standard operating procedures of a job have ranked highest.The results of this study indicate that the workability of employees has influenced employee performance.The results of this test have explained that the technical capabilities of employees guided by correct work procedures have affected employees in completing all types of work on time.The results of this study are similar to the research of Syardiano (2014) who conducted a study with respondents from the Department of Transportation staff in the Indonesian government, the results of the study proved that the workability of employees had a positive impact on performance. Of course, both of these studies have the same resemblance that the respondents are government employees who have the same function of serving the community. The practical implication of this research finding is that all-important government employees should be given the ability to work for the purpose of improving the quality, quantity, and timeliness of work.

Sopiah (2010) has explained about organizational commitment.

He has said that organizational commitment is part of individual behavior to survive as a member of the organization.Sophia's view (2010) according to the researcher is a general view. In particular, organizational commitment in this study is measured by willingness, loyalty, and pride in being an employee. The results of this study indicate that employee commitment to the organization can affect employee performance.The willingness of employees to provide services to the community has had a positive impact on the performance of the land office 
employees. The findings of this study support the findings of Kusnadi (2011) which links between organizational commitment and individual performance.

The results of this study also support the study of Salma (2016) who examined health workers as respondents.Health workers have the same function as government employees, namely serving the community.The results of this study can be applied in general that employees who carry out the task of serving the community need a commitment to the workplace organization.

Siagian (2000) has explained about the professionalism of employees is the sincerity of employees to work quality and be able to use time effectively for work achievement.Professionalism is very necessary, especially for organizations that have a clear vision and mission. Professionalism in this study is measured by employee creativity, innovation, and employee responsiveness.Employee responsiveness in carrying out leadership instructions quickly as the findings of this research. The results of this study have shown that the professionalism of employee work as shown by responding quickly to each leader of the organization's instructions has an impact on the performance of employees, especially employees who are able to complete the work on time according to the time determined by the organization. The results of this study are relatively similar to the results of the study of Widura et al. (2017).Widura et al. (2017) examine the relationship between professionalism and individual performance. Government employees as research respondents. The results of the study by Widura et al. (2017) have proven that the work professionalism of employees influences individual performance.

Some explanations about the results of this study compared with the results of previous studies can be concluded that employees who do service to the community really need ability, commitment to the organization and professionals. If these three things are met, the opportunity to achieve quality, quantity, and timeliness in work is very high.

\section{Conclusion}

Some of the findings of this study are that government employees have good workability, are able to technically carry out work procedures, have the commitment to spend time serving the community, employees work professionally especially have the speed of responding to work, and most employees are able to complete work on time.

The results showed that workability, organizational commitment and work professionalism of employees can affect the performance of employees of the Land offices in Malang City.Technical workability, commitment to service and professionalism in responding quickly to leadership instructions have a positive impact on employee performance in completing work on time.Employee workability predominantly affects employee performance. Thus improving the performance of employees in the Land Offices is strongly influenced by creativity, innovation and employee responsiveness.

\section{Limitations and Future Research}

This research does not consider aspects of work culture in the government environment.

The governance environment in Indonesia related to work culture can be divided into several levels of work ethic.Government offices that have high work targets due to political factors generally have a high level of operational performance.Unlike the government offices that have a small budget, their performance is certainly not high.Land Offices in Indonesia are on average high performance, therefore work ethic is a new variable that needs to be investigated to determine the exact position. So that the suggested structural model is to be tested for future researchers in a high-performance government environment as shown in figure 1 below.

Figure 1. Equation model for future research

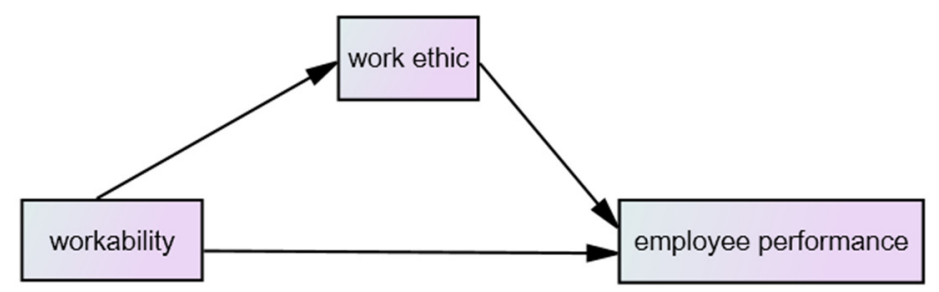

\section{References}

Badan Pusat Statistik. 2017. Propinsi Jawa Timur dalam angka 2017. Katalog BPS : 110200135

Direktorat Jenderal Infrasruktur Keagrarian. 2017. Laporan Kinerja 2017 Direktorat Jenderal Infrasruktur Keagrarian.

Mangkunegara, AA. Anwar Prabu. 2014.Manajemen Sumber Daya Manusia Perusahaan. PT. Remaja Rosdakarya, Bandung. 
Nunnally,JC and Bernstein,LH.1994. Psychometric Theory, 3rd ed., McGraw-Hill, New York, NY

Robbins, Stephen. 2011. Perilaku Organisasi. Jakarta: Penerbit Prenhallindo.

Robbins, Stephen P dan Judge, Timothy A. 2013. Organizational Behavior Edition 15. New Jersey: Pearson Education.

Salma, D. 2016. Pengaruh Komitmen Organisasi, Motivasi Kerja dan Pengalaman Kerja Terhadap Kinerja Pegawai Honor Lepas Pada Puskesmas Di Kabupaten Morowali. e Jurnal Katalogis. Universitas Tadulako. Volume 4 Nomor 8: 73-84.

Sedarmayanti. 2011. Manajemen Sumber Daya Manusia, Reformasi Birokrasi dan Manajemen Pegawai Negeri Sipil. Cetakan Kelima. Bandung: PT.Refika Aditama.

Siagian, Sondang P. 2009. Manajemen Sumber Daya Manusia. Jakarta: Bumi Aksara.

Sopiah. 2010. Manajemen Bisnis Ritel. Yogyakarta: Penerbit Andi.

Sutrisno, Edy. 2012. Manajemen Sumber Daya Manusia. Jakarta: Kencana Prenada Media Group

Syardianto, Djumadi dan Bambang Irawan. 2014. Pengaruh Kemampuan Kerja dan Motivasi Kerja terhadap Kinerja Pegawai Pada Dinas Perhubungan Komunikasi dan Informatika Kabupaten Kutai Timur. e-Journal Administrative Reform. Vol. 2 No. 1 : 885-897.

Windura, Bobbie, Raja Adri Satriawan dan Sem Paulus Silalahi. 2017. Pengaruh Gaya Kepemimpinan, Profesionalisme, Lingkungan Kerja dan Kecerdasan Emosional terhadap Kinerja Pengelola Keuangan (Studi Pada SKPD Kota Dumai). JOM Fekon. Vol. 4. No. 1: 1022-1036 